\title{
Stable isotopes of carbon dioxide in soil gas over massive sulfide mineralization at Crandon, Wisconsin
}

\author{
Charles N. Alpers ${ }^{\mathrm{a}, 1}$, David L. Dettman ${ }^{\mathrm{b}}$, Kyger C. Lohmann $^{\mathrm{b}}$ and \\ Dragan Brabec ${ }^{\mathrm{C}}$ \\ ${ }^{a}$ U.S. Geological Survey, 345 Middlefield Road, Mailstop 420, Menlo Park, CA 94025, U.S.A. \\ ${ }^{b}$ Dept. of Geological Sciences, University of Michigan, 1006 C. C. Little Bldg., Ann Arbor, MI 48109. \\ I063, U.S.A. \\ '4011 W. 37th Ave., Vancouver, B.C. V6N 2W6, Canada
}

(Received January 12, 1989; revised and accepted September 14, 1989)

\begin{abstract}
Alpers, C.N., Dettman, D.L., Lohmann, K.C. and Brabec, D., 1990. Stable isotopes of carbon dioxide in soil gas over massive sulfide mineralization at Crandon, Wisconsin. In: S.E. Kesler (Editor), Soil and Rock Gas Geochemistry. J. Geochem. Explor., 38: 69-86.
\end{abstract}

Stable isotope ratios of oxygen and carbon were determined for $\mathrm{CO}_{2}$ in soil gas in the vicinity of the massive sulfide deposit at Crandon, Wisconsin with the objective of determining the source of anomalously high $\mathrm{CO}_{2}$ concentrations detected previously by McCarthy et al. (1986). Values of $\delta^{13} \mathrm{C}$ in soil gas $\mathrm{CO}_{2}$ from depths between 0.5 and $1.0 \mathrm{~m}$ were found to range from $-12.68 \% 0$ to $-20.03 \% 0$ (PDB). Organic carbon from the uppermost meter of soil has $\delta^{13} \mathrm{C}$ between -24.1 and $-25.8 \%$ (PDB), indicating derivation from plant species with the $C_{3}$ (Calvin) type of photosynthetic pathway. Microbial decomposition of the organic carbon and root respiration from $\mathrm{C}_{3}$ and $\mathrm{C}_{4}$ (HatchSlack ) plants, together with atmospheric $\mathrm{CO}_{2}$ are the likely sources of carbon in soil gas $\mathrm{CO}_{2}$. Values of $\delta^{18} \mathrm{O}$ in soil-gas $\mathrm{CO}_{2}$ range from 32 to $38 \%$ (SMOW). These $\delta^{18} \mathrm{O}$ values are intermediate between that calculated for $\mathrm{CO}_{2}$ gas in isotopic equilibrium with local groundwaters and that for atmospheric $\mathrm{CO}_{2}$. The $\delta^{18} \mathrm{O}$ data indicate that atmospheric $\mathrm{CO}_{2}$ has been incorporated by mixing or diffusion. Any $\mathrm{CO}_{2}$ generated by microbial oxidation of organic matter has equilibrated its oxygen isotopes with the local groundwaters.

The isotopic composition of soil-gas $\mathrm{CO}_{2}$ taken from directly above the massive sulfide deposit was not distinguishable from that of background samples taken 1 to $2 \mathrm{~km}$ away. No enrichment of the $\delta^{13} \mathrm{C}$ value of soil-gas $\mathrm{CO}_{2}$ was observed, contrary to what would be expected if the anomalous $\mathrm{CO}_{2}$ were derived from the dissolution of Proterozoic marine limestone country rock or of Paleozoic limestone clasts in glacial till. Therefore, it is inferred that root respiration and decay of $\mathrm{C}_{3}$ plant material were responsible for most $\mathrm{CO}_{2}$ generation both in the vicinity of the massive sulfide and in the "background" area, on the occasion of our sampling. Interpretation of our data is complicated by the effects of rainfall, which significantly reduced the magnitude of the $\mathrm{CO}_{2}$ anomaly. Therefore, we cannot rule out the possible mechanism of carbonate dissolution driven by pyrite oxidation, as proposed by Lovell et al. (1983) and McCarthy et al. (1986). Further work is needed on seasonal and daily variations of $\mathrm{CO}_{2}$ concentrations and stable isotope ratios in various hydrogeologic and ecologic settings so that more effective sampling strategies can be developed for mineral exploration using soil gases.

\footnotetext{
${ }^{1}$ Present address: Dept. of Geological Sciences, McGill University, 3450 University St., Montréal, Qué. H3A 2A7, Canada.
} 


\section{INTRODUCTION}

Exploration for sulfide ore deposits presents special challenges in areas where bedrock is concealed beneath transported overburden such as glacial till or alluvium. In these environments, traditional surface geochemistry is unlikely to provide meaningful results. Soil-gas geochemistry can potentially provide information about the underlying rock types, structure and mineralogy in such terrain. Anomalously high $\mathrm{CO}_{2}$ concentrations have been documented over several oxidizing sulfide deposits (Hale and Moon, 1982; Lovell et al., 1983; Clifton, 1984a,b; McCarthy et al., 1986). However, the source of $\mathrm{CO}_{2}$ in this environment and the mechanism for its generation have not been determined.

This paper describes results of a preliminary attempt to determine the source of the $\mathrm{CO}_{2}$ in soil gases overlying massive sulfide mineralization at Crandon, Wisconsin, using stable isotope techniques. We sought to investigate the hypothesis that anomalously high $\mathrm{CO}_{2}$ concentrations in soil gas at Crandon are produced by a different mechanism than the background $\mathrm{CO}_{2}$ concentrations and therefore would have a different isotopic signature. Our goal in part was to evaluate the potential utility of $\mathrm{C}$ and $\mathrm{O}$ isotopic analysis of $\mathrm{CO}_{2}$ as a means to discriminate between $\mathrm{CO}_{2}$ produced in response to sulfide oxidation as opposed to background or "normal" soil $\mathrm{CO}_{2}$ in a given area.

\section{PREVIOUS WORK}

Dissolution of carbonate minerals by sulfuric acid solutions resulting from sulfide oxidation is the mechanism proposed by Lovell et al. (1983) for $\mathrm{CO}_{2}$ generation above three oxidizing sulfide deposits. Clifton (1984b) maintained that the source of $\mathrm{CO}_{2}$ in carbonate-poor soils is oxidization of organic matter; he suggested that the $\mathrm{CO}_{2}$ flux in fractured igneous terrains may provide a measure of the surface area available for bacterial degradation of organic matter, and therefore may indicate the degree of fracturing. Wallick et al. (1984) noted a significant difference between the $\delta^{13} \mathrm{C}$ of soil-gas $\mathrm{CO}_{2}$ at two nearby mines in Alberta, Canada, and suggested that a mixture of organic carbon $\left(\delta^{13} \mathrm{C}=-21\right.$ to $-17 \%$ PDB $)$ and marine carbonate ( $\sim 0 \%$ ) provided the source of the carbon in soil $\mathrm{CO}_{2}$ at those sites.

Plant respiration through roots as a source of $\mathrm{CO}_{2}$ in soils was considered of secondary importance in the studies cited above, however, root respiration together with the decomposition of plant-derived organic matter are likely to be the major sources of soil $\mathrm{CO}_{2}$ in moderately to densely vegetated settings (Lerman, 1972; Cerling et al., 1977; Deines, 1980; Dörr and Münnich, 1980; Buyanovsky and Wagner, 1983; Cerling, 1984; Salomons and Mook, 1986). The role of $\mathrm{CO}_{2}$ accumulation due to root respiration in soils depends on numerous factors affecting biological activity (temperature, humidity, nu- 
trient concentrations) and the physical properties of the soil (porosity, structure, density, and moisture content) (Buyanovsky and Wagner, 1983). Seasonal variations of $\mathrm{CO}_{2}$ partial pressures in soil gas are well known (e.g., Lundegardh, 1927; Rightmire, 1978; Reardon et al., 1979; Buyanovsky and Wagner, 1983). The $\delta^{13} \mathrm{C}$ of soil $\mathrm{CO}_{2}$ and of dissolved carbonate species are strongly influenced by the $\delta^{13} \mathrm{C}$ of local vegetation (Rightmire and Hanshaw, 1973; Cerling, 1984; Cerling and Hay, 1986; Amundson et al., 1988). Understanding the distribution of $\delta^{13} \mathrm{C}$ in soil-gas $\mathrm{CO}_{2}$ is also important to interpretation of ${ }^{14} \mathrm{C}$ dating of groundwater systems open to recharge through the soil zone because of necessary assumptions regarding the initial $P_{\mathrm{CO}_{2}}$ of infiltrating groundwater and its $\delta^{13} \mathrm{C}$ composition (Lerman, 1972; Wigley, 1975; Wallick, 1976; Reardon et al., 1979; Parada et al., 1983; White and Chuma, 1987).

The $\delta^{13} \mathrm{C}$ of plants and their respiration products depends on characteristic photosynthetic pathways (Bender, 1968, 1971; Smith and Epstein, 1971; Deines, 1980; Hillaire-Marcel, 1986). The $C_{3}$ (or Calvin) cycle (Calvin and Bassham, 1962) is common to trees, grasses and shrubs in temperate areas, whereas the $\mathrm{C}_{4}$ (or Hatch-Slack) cycle (Hatch et al., 1967) is more typical of grasses in tropical and arid climates (Talma and Netterberg, 1983). The ranges of $\delta^{13} \mathrm{C}$ for $\mathrm{C}_{3}$ and $\mathrm{C}_{4}$ vegetation are, respectively, -21 to $-33 \%$ (PDB) (mean of -26 to $-28 \%$ ) and -10 to $-19 \%$ (mean of -12 to $-14 \%$ ) (Deines, 1980; Hillaire-Marcel, 1986). Seasonal variations in soil $\mathrm{CO}_{2}$ concentration and $\delta^{13} \mathrm{C}$ can result at a locality with mixed $\mathrm{C}_{3}$ and $\mathrm{C}_{4}$ vegetation because of a seasonal variation in photosynthetic activity (Rightmire, 1978; Ode et al., 1980; Buyanovsky and Wagner, 1983; Talma and Netterberg, 1983 ). A third type of photosynthetic cycle, known as Crassulacean acid metabolism (CAM) results in $\delta^{13} \mathrm{C}$ depletion intermediate between $\mathrm{C}_{3}$ and $\mathrm{C}_{4}$ vegetation (Kluge and Ting, 1978; Hillaire-Marcel, 1986).

Recent studies of soil $\mathrm{CO}_{2}$ and pedogenic carbonate have investigated the use of the $\delta^{13} \mathrm{C}$ and $\delta^{18} \mathrm{O}$ of calcretes as paleoclimatic indicators (Margaritz et al., 1981; Cerling, 1984; Cerling and Hay, 1986; Amundson et al., 1988; Quade et al., 1989). An important assumption in these studies, backed up by a limited number of direct observations (e.g., Amundson et al., 1988), is that pedogenic carbonates form in isotopic equilibrium with the soil environment. In a study of the unsaturated zone in southeastern Nevada, White and Chuma (1987) showed $\mathrm{CO}_{2}$ to be in isotopic and solubility equilibrium between gas and water in the soil zone. We will show below that attainment of isotopic equilibrium is an important factor in the interpretation of $\delta^{18} \mathrm{O}$ in soil $\mathrm{CO}_{2}$.

\section{SITE DESCRIPTION}

The massive sulfide deposit at Crandon, Wisconsin (Fig. 1) was discovered in 1975 by Exxon using results of airborne electromagnetic surveys fol- 


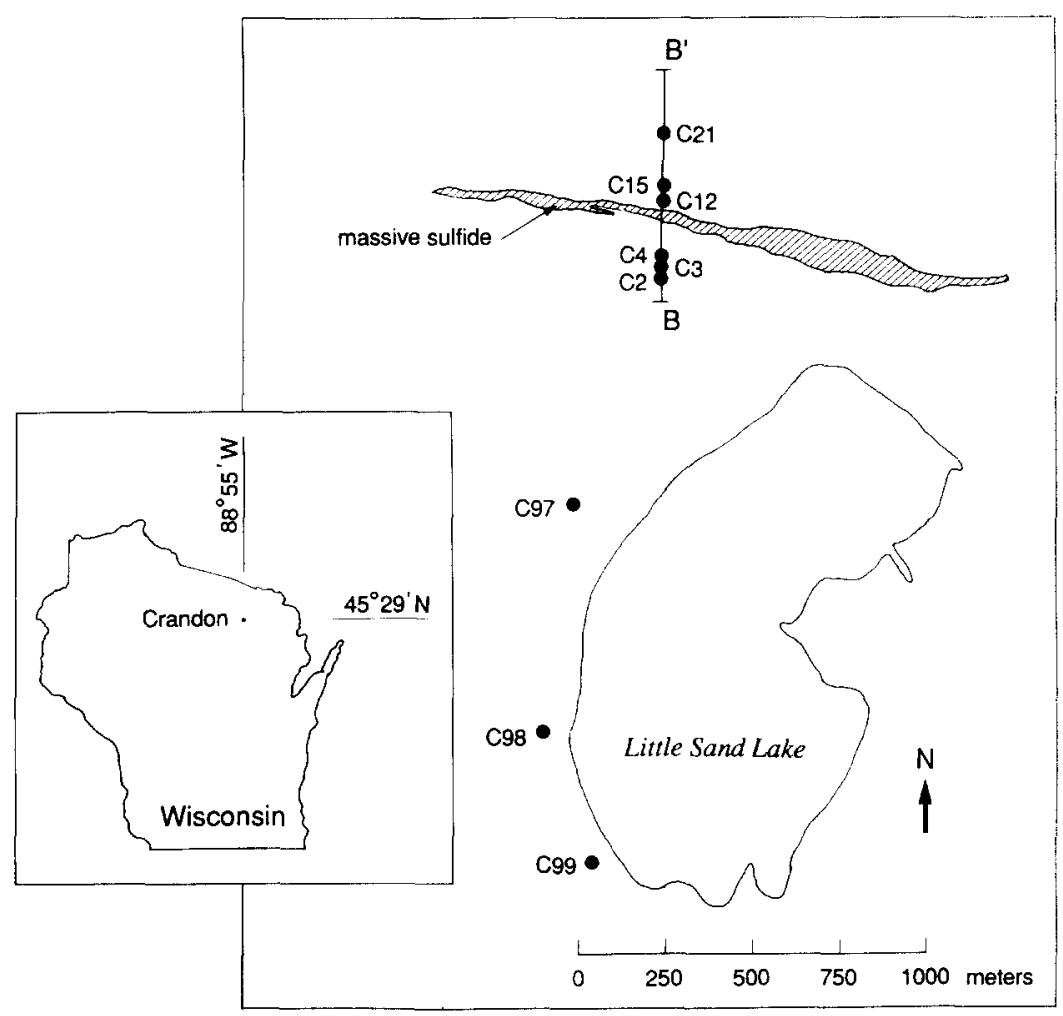

Fig. 1. Location of soil-gas samples at Crandon, Wisconsin.

lowed up by ground surveys using horizontal loop EM, induced polarization, and gravity (Schmidt et al., 1978). Analysis of 198 diamond-drill holes by Exxon confirmed a deposit of 62 million tons averaging $5 \% \mathrm{Zn}$ and $1 \% \mathrm{Cu}$ (May and Schmidt, 1982).

The Crandon deposit lies conformably within a steeply dipping sequence of dacitic volcanic rocks and their sedimentary derivatives of probable Proterozoic X (Early Proterozoic) age (May and Schmidt, 1982; McCarthy et al., 1986). The regional strike of all units is about $N 85^{\circ} \mathrm{W}$, with a dip of $85^{\circ} \mathrm{N}$. Stratigraphic tops are inferred to face north based on mineral zoning and relict depositional features (May and Schmidt, 1982).

Footwall rocks include andesitic flows and tuffs, porphyritic basalt flows, and a variety of volcano-sedimentary breccias that have been variably silicified, sericitized, and pyricized (May and Schmidt, 1982; McCarthy et al., 1986). The Crandon unit, which contains the massive sulfide ore, is part of a tabular lens of chemical sedimentary rocks and fine clastics that has a maximum thickness of $100 \mathrm{~m}$. Hanging-wall rocks are comprised of andesitic to 
rhyolitic tuffs and flows with rare intervals of massive sulfide and pyritic tuff, showing minimal hydrothermal alteration (May and Schmidt, 1982; McCarthy et al., 1986).

The bedrock at Crandon is overlain by 25 to $65 \mathrm{~m}$ of Pleistocene glacial drift. The lower part of the drift is nonsorted, nonstratified glacial till, overlain by stratified glacial outwash deposits which make up the primary groundwater aquifer in the area (McCarthy et al., 1986). The stratified deposits are composed of calcareous gravel and sand-sized material with less than $10 \%$ clay- and silt-sized fraction (McCarthy et al., 1986). Between 1982 and 1986, the groundwater table was located generally at least $10 \mathrm{~m}$ above the base of the glacial drift (McCarthy et al., 1986); however, it remains possible that the massive sulfide mineralization has been exposed to unsaturated conditions in densely fractured zones of higher permeability.

\section{SAMPLING TECHNIQUES AND ANALYTICAL METHODS}

Initial measurements of $\mathrm{CO}_{2}$ for this study were made on October 5-7, 1986 along traverse B-B' (Fig. 1) to confirm the previously documented $\mathrm{CO}_{2}$ anomaly overlying the sulfide mineralization (McCarthy et al., 1986) and to guide the collection of soil-gas samples for isotopic analysis. Soil-gas samples of $2 \mathrm{~cm}^{3}$ were taken at depths from 40 to $50 \mathrm{~cm}$ using a sampling device similar to that described by Ball et al. (1983): a stainless steel probe $70 \mathrm{~cm}$ long, with an internal diameter of $6 \mathrm{~mm}$. Measurements of $\mathrm{CO}_{2}$ concentration were made using a portable, infrared $\mathrm{CO}_{2}$ meter (model RI-411), calibrated by a mixture of $0.5 \% \mathrm{CO}_{2}$ in air.

Additional soil-gas sampling for isotopic analysis was carried out at six sites along traverse B-B', plus three "background" sites located 1 to $2 \mathrm{~km}$ south of the deposit (Fig. 1). These soil-gas samples were collected on October 21-22, 1986 using a hollow steel probe with the following dimensions: 2-m length, 4$\mathrm{mm}$ internal diameter, $2-\mathrm{cm}$ outer diameter, and $15-\mathrm{cm}^{3}$ volume. Six holes on the probe's tapered tip allowed gas entry. The top of the tube was fitted with a $10-\mathrm{kg}$ sliding weight, used to drive the tube into the ground. A port in the side of the unit allowed emplacement of a side-port needle through which the sample was extracted. Steel containers resembling aerosol cans of $325-\mathrm{cm}^{3}$ volume were evacuated in the laboratory prior to sampling and were fitted with self-sealing teflon ports.

Gas and soil samples for isotopic analysis were collected at depths from 0.5 to $1.0 \mathrm{~m}$ at each of the six sites selected on traverse B-B' plus the three background sites (Fig. 1; Table 1). After penetration of the probe to the desired depth, one minute was allowed for equilibration and then the needle was inserted into the evacuated container for two minutes. Sampling at six sites on Traverse B-B' ${ }^{\prime}$ was carried out on the afternoon of October 21, 1986; two of the sites were resampled the following morning, along with the three back- 


\section{TABLE 1}

Geochemical and isotopic data for Crandon soil gases ${ }^{a, b}$

\begin{tabular}{|c|c|c|c|c|c|c|c|c|}
\hline \multirow[t]{2}{*}{ Sample } & \multirow{2}{*}{$\begin{array}{l}\text { Depth } \\
(\mathrm{m})\end{array}$} & \multicolumn{2}{|c|}{ Collection } & \multirow{2}{*}{$\begin{array}{l}\delta^{18} \mathrm{O} \\
(\% \text { SMOW })\end{array}$} & \multirow{2}{*}{$\begin{array}{l}\delta^{13} \mathrm{C} \\
(\% 0 \mathrm{PDB})\end{array}$} & \multirow{2}{*}{$\begin{array}{l}\mathrm{CO}_{2} \\
(\mathrm{ppm})\end{array}$} & \multirow{2}{*}{$\begin{array}{l}\mathrm{SO}_{2} \\
(\mathrm{ppm})\end{array}$} & \multirow{2}{*}{$\begin{array}{l}\mathrm{CH}_{4} \\
(\mathrm{ppm})\end{array}$} \\
\hline & & Date $^{c}$ & Time & & & & & \\
\hline $\mathrm{C} 2-\mathrm{G} 1$ & 1.0 & $10 / 21$ & $14: 20$ & 37.5 & -16.3 & 439 & 0.8 & 2 \\
\hline $\mathrm{C} 2-\mathrm{G} 2$ & 0.5 & $10 / 21$ & $14: 25$ & 36.9 & -17.4 & 1421 & 0.2 & 3 \\
\hline $\mathrm{C} 3-\mathrm{G} 1$ & 0.5 & $10 / 21$ & $13: 50$ & 37.0 & -14.5 & 636 & 0.1 & 6 \\
\hline C3-G2 & 0.5 & $10 / 21$ & $14: 00$ & 36.0 & -16.2 & 327 & 0.2 & 8 \\
\hline C4-GI & 1.0 & $10 / 21$ & $13: 00$ & 34.3 & -14.0 & 412 & 0.1 & 7 \\
\hline $\mathrm{C} 4-\mathrm{G} 2$ & 0.5 & $10 / 21$ & $13: 07$ & 35.7 & -12.6 & 516 & $N^{d}$ & 2 \\
\hline $\mathrm{Cl} 2-\mathrm{G} 1 \mathrm{~A}$ & 0.9 & $10 / 21$ & $16: 59$ & 35.7 & -17.1 & 569 & 0.2 & 5 \\
\hline C12-G1B & 0.9 & $10 / 21$ & $17: 03$ & 32.7 & -16.4 & 1337 & ND & ND \\
\hline $\mathrm{C} 12-\mathrm{G} 2$ & 0.5 & $10 / 21$ & $17: 13$ & 34.6 & -15.3 & 666 & 0.1 & ND \\
\hline $\mathrm{C} 12-\mathrm{G} 3 \mathrm{~A}$ & 0.9 & $10 / 22$ & $7: 46$ & 35.6 & -14.5 & 741 & 0.1 & 2 \\
\hline C12-G3B & 0.9 & $10 / 22$ & $7: 49$ & 35.5 & -13.7 & 909 & 0.3 & 5 \\
\hline C15-G1A & 0.6 & $10 / 21$ & $16: 22$ & 37.1 & -14.7 & 610 & ND & ND \\
\hline C15-G1B & 0.6 & $10 / 21$ & $16: 25$ & 37.3 & -13.4 & 747 & ND & 5 \\
\hline $\mathrm{C} 15-\mathrm{G} 2$ & 0.9 & $10 / 21$ & $16: 34$ & 37.0 & -16.3 & 933 & ND & 6 \\
\hline $\mathrm{C} 15-\mathrm{G} 3$ & 0.6 & $10 / 22$ & $8: 06$ & 35.4 & -17.2 & 617 & ND & ND \\
\hline C21-G1 & 1.0 & $10 / 21$ & $17: 41$ & 37.1 & -15.5 & 4146 & ND & 1 \\
\hline $\mathrm{C} 21-\mathrm{G} 2$ & 0.5 & $10 / 21$ & $17: 55$ & 35.2 & -20.0 & 613 & ND & 2 \\
\hline $\mathrm{C} 97-\mathrm{Gl}$ & 0.9 & $10 / 22$ & $8: 28$ & 36.2 & -14.8 & 673 & ND & 3 \\
\hline C98-G1 & 0.9 & $10 / 22$ & $8: 45$ & 35.4 & -17.4 & $(40)^{\mathrm{e}}$ & ND & 1 \\
\hline C99-Gl & 0.9 & $10 / 22$ & $9: 03$ & 35.8 & -17.8 & 71 & ND & 2 \\
\hline
\end{tabular}

${ }^{a}$ Isotopic analyses carried out at the University of Michigan, Dept. of Geological Sciences; chemical analyses by DataChem, Salt Lake City, Utah.

${ }^{b} \mathrm{COS}, \mathrm{CS}_{2}, \mathrm{H}_{2} \mathrm{~S}, \mathrm{C}_{2} \mathrm{H}_{6}, \mathrm{C}_{3} \mathrm{H}_{8}$ were analysed for, but not detected in any of the samples; detection limit approximately $1 \mathrm{ppm}$ (D. Osborne, pers. commun., 1988).

'Dates refer to calendar year 1986 (month/day).

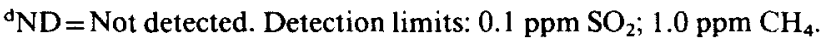

${ }^{\mathrm{e}} \mathrm{Amount}$ in parentheses represents trace amount of $\mathrm{CO}_{2}$ near limit of detection (D. Osborne, pers. commun., 1988).

ground sites (Table 1). Three samples were taken in duplicate without moving the probe (A, B suffixes, Table 1 ) to determine if the extent of air contamination varied with time.

In total, 20 gas and soil samples were collected. All gas samples were analyzed for $\mathrm{CO}_{2}, \mathrm{SO}_{2}, \mathrm{COS}, \mathrm{CS}_{2}, \mathrm{H}_{2} \mathrm{~S}, \mathrm{CH}_{4}, \mathrm{C}_{2} \mathrm{H}_{6}$, and $\mathrm{C}_{3} \mathrm{H}_{8}$ by gas chromatography/mass spectrometry and for carbon and oxygen isotope enrichments 
in $\mathrm{CO}_{2}$, expressed as $\delta^{13} \mathrm{C}(\mathrm{PDB})$ and $\delta^{18} \mathrm{O}$ (SMOW) (Table 1). $\mathrm{CO}_{2}$ was extracted from soil-gas samples by slowly evacuating the sample containers through two liquid-nitrogen traps. Stable isotopes were analyzed using a VG$602 \mathrm{E}$ gas ratio mass spectrometer.

Nine soil samples were selected for analysis of total organic carbon and total organic nitrogen using standard methods. Trace amounts of carbonate were removed from the samples by digestion in weak $\mathrm{HCl}$; in all samples, carbonate made up less than $3 \mathrm{wt} . \%$ of the soil. The decarbonatized samples were analyzed by mass spectrometry to determine the $\delta^{13} \mathrm{C}$ of remaining organic carbon by oxidation with cupric oxide in sealed Pyrex ${ }^{\circledast}$ tubes at $500^{\circ} \mathrm{C}$. Gas was desorbed from the nine selected soil samples by heating to $170^{\circ} \mathrm{C}$ at $10^{\circ} \mathrm{C} \mathrm{m^{-1 }}$, and then analyzed by gas chromatography/mass spectrometry to determine the relative abundances of adsorbed $\mathrm{CO}_{2}, \mathrm{SO}_{2}, \mathrm{COS}, \mathrm{CS}_{2}, \mathrm{H}_{2} \mathrm{~S}$, $\mathrm{CH}_{4}, \mathrm{C}_{2} \mathrm{H}_{6}$ and $\mathrm{C}_{3} \mathrm{H}_{8}$. Table 2 shows results of soil desorption, organic- carbon and organic-nitrogen determinations, and the $\delta^{13} \mathrm{C}$ of organic carbon.

Groundwaters from two drill holes in the district were sampled for chemical and isotopic analysis (Table 3 ). A 5-kg-grab sampler was used to collect samples from 0.5 to $2 \mathrm{~m}$ below the water table.

\section{TABLE 2}

Geochemical and isotopic data for Crandon soils and desorbed gases

\begin{tabular}{|c|c|c|c|c|c|c|c|c|c|}
\hline \multirow[t]{2}{*}{ Sample } & \multicolumn{3}{|c|}{ Total soil ${ }^{a}$} & \multicolumn{6}{|c|}{ Desorbed gas $^{b}(\mathrm{ppm})$} \\
\hline & $\begin{array}{l}N_{o r g}^{c} \\
\text { (wt. } \%)\end{array}$ & $\begin{array}{l}\mathrm{C}_{\text {org }}{ }^{\mathrm{d}} \\
\text { (wt. } \% \text { ) }\end{array}$ & $\begin{array}{l}\delta^{13} \mathrm{C}_{\text {ors }} \\
\text { (\%o PDB) }\end{array}$ & $\mathrm{CO}_{2}$ & $\mathrm{CH}_{4}$ & $\mathrm{C}_{2} \mathrm{H}_{6}$ & $\mathrm{C}_{3} \mathrm{H}_{8}$ & $\mathrm{H}_{2} \mathrm{~S}$ & COS \\
\hline C2-G1-S & 0.12 & 0.14 & -24.7 & 391 & $(0.05)^{e}$ & $\mathrm{ND}^{r}$ & 3.0 & ND & ND \\
\hline C2-G2-S & 0.07 & 0.78 & -25.0 & 3467 & 0.2 & 0.1 & 12.4 & $(0.05)$ & 0.1 \\
\hline C12-G1-S & 0.14 & 1.93 & -25.8 & 455 & 0.1 & ND & 6.6 & ND & ND \\
\hline C12-G2-S & ND & 0.12 & -24.7 & 181 & 0.1 & ND & 1.6 & ND & ND \\
\hline C12-G3-S & 0.46 & 9.42 & -25.4 & 2504 & 0.1 & $(0.05)$ & 4.9 & ND & ND \\
\hline C21-GI-S & 0.05 & 0.80 & -24.9 & 1053 & 0.1 & 0.1 & 3.5 & ND & ND \\
\hline C21-G2-S & 0.07 & 1.18 & -24.7 & 1470 & 0.2 & 0.1 & 36.9 & ND & ND \\
\hline C98-G1-S & 0.10 & 1.43 & -25.7 & 1671 & 0.1 & $(0.05)$ & 3.8 & ND & ND \\
\hline C99-G1-S & 0.11 & 1.60 & -25.3 & 2966 & 0.2 & 0.1 & 16.1 & ND & ND \\
\hline Mean & 0.12 & 1.93 & -25.1 & & & & & & \\
\hline Std.dev. & 0.13 & 2.9 & 0.4 & & & & & & \\
\hline
\end{tabular}

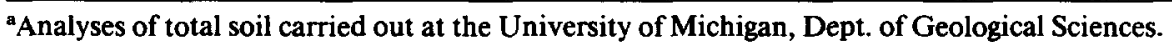

${ }^{b}$ Analyses of desorbed gas by DataChem, Salt Lake City, Utah; D. Osborne and G. Juliani, analysts.

'Total organic nitrogen.

${ }^{\mathrm{d}}$ Total organic carbon; total carbonate in all samples was found to be less than 3.0 weight percent by gravimetric methods.

${ }^{\prime}(0.05)$ represents trace amount at lower limit of detection (as reported by DataChem).

${ }^{\mathrm{f}} \mathrm{ND}=$ Not detected; detection limits: $\mathrm{N}_{\text {org }}=0.05 \mathrm{wt} . \% ; \mathrm{C}_{2} \mathrm{H}_{6}=0.05 \mathrm{ppm} ; \mathrm{H}_{2} \mathrm{~S}=0.05 \mathrm{ppm} ; \mathrm{COS}=0.05$ ppm. 
TABLE 3

Chemical and isotopic composition of two Crandon groundwater samples and calculated isotopic composition of coexisting $\mathrm{CO}_{2}$ gas

\begin{tabular}{|c|c|c|c|}
\hline Parameter & Units & X-3-W1 & X-4-W1 \\
\hline $\mathrm{pH}$ & & 7.0 & 7.3 \\
\hline Conductance & $\mu$ mhos $\mathrm{cm}^{-1}$ & 114 & 253 \\
\hline $\mathrm{Na}$ & $\mathrm{mg} \mathrm{I}^{-1}$ & 10.6 & 14.3 \\
\hline $\mathrm{Mg}$ & $\mathrm{mg} \mathrm{I}^{-1}$ & 4.2 & 12.5 \\
\hline $\mathrm{Ca}$ & $\mathrm{mg} \mathrm{l}^{-1}$ & 7.3 & 18.2 \\
\hline $\mathrm{K}$ & $\mathrm{mg} \mathrm{l}^{-1}$ & 2.7 & 3.9 \\
\hline $\mathrm{SO}_{4}$ & $\mathrm{mg} \mathrm{l}^{-1}$ & 14.4 & $<5.0$ \\
\hline $\mathrm{HCO}_{3}$ & $\mathrm{mg} \mathrm{l}^{-1}$ & 56 & 140 \\
\hline $\mathrm{CO}_{3}$ & $\mathrm{mg} \mathrm{l}^{-1}$ & 0 & 0 \\
\hline $\mathrm{NO}_{3}$ & $\mathrm{mg} \mathrm{l}^{-1}$ & 0.01 & 0.01 \\
\hline $\mathrm{PO}_{4}$ & $\mathrm{mg} \mathrm{1}^{-1}$ & $<0.1$ & $<0.1$ \\
\hline $\mathrm{Cl}$ & $\mathrm{mg} \mathrm{l}^{-1}$ & 3.4 & 12.2 \\
\hline $\mathrm{Cu}$ & $\mathrm{mg} \mathrm{l}^{-1}$ & $<0.01$ & 0.01 \\
\hline $\mathrm{Fe}$ & $\mathrm{mg} \mathrm{l}^{-1}$ & 0.3 & 0.5 \\
\hline Mn & $\mathrm{mg} \mathrm{l}^{-1}$ & 0.1 & $<0.1$ \\
\hline $\mathrm{Zn}$ & $\mathrm{mg} \mathrm{l}^{-1}$ & 0.1 & $<0.1$ \\
\hline $\mathrm{Si}$ & $\mathrm{mg} \mathrm{l}^{-1}$ & $<1$ & $<1$ \\
\hline Charge balance & $\operatorname{meq} 1^{-1}$ & -0.04 & +0.05 \\
\hline$\delta^{18} \mathrm{O}$ of water & $\%$ (SMOW) & -11.4 & -11.2 \\
\hline$\delta^{18} \mathrm{O}$ of $\mathrm{CO}_{2}$ gas & $\%$ (SMOW) & & \\
\hline in equilibrium & $@ 25^{\circ} \mathrm{C}$ & 29.4 & 29.6 \\
\hline with water (calculated) $)^{\mathbf{a}}$ & $@ 15^{\circ} \mathrm{C}$ & 31.4 & 31.6 \\
\hline
\end{tabular}

aThe fractionation of $\delta^{18} \mathrm{O}$ between water and coexisting $\mathrm{CO}_{2}$ gas is: $10^{3} \ln \alpha=16.60\left(10^{3} \mathrm{~T}^{-1}\right)-15.19$ (Friedman and O'Neil, 1977).

\section{RESULTS}

$\mathrm{CO}_{2}$ concentrations in soil gas from sampling on October 5-7, 1986 along traverse B-B' are shown in Figure 2. The highest $\mathrm{CO}_{2}$ concentrations detected in this study were found in the vicinity of massive sulfide and disseminated (low grade) sulfide mineralization, confirming the anomaly outlined by McCarthy et al. (1986). Soil gas taken for isotopic analysis along traverse B$B^{\prime}$ were taken at more than one depth at five locations. In general, $\mathrm{CO}_{2}$ concentrations are observed to increase with depth within the top meter of most soils because most soil $\mathrm{CO}_{2}$ is produced at greater depth from root respiration and bacterial oxidation of organic matter. Concentration profiles of $\mathrm{CO}_{2}$ are thought to be strongly influenced by diffusion effects (Von Bavel, 1951; Cer- 


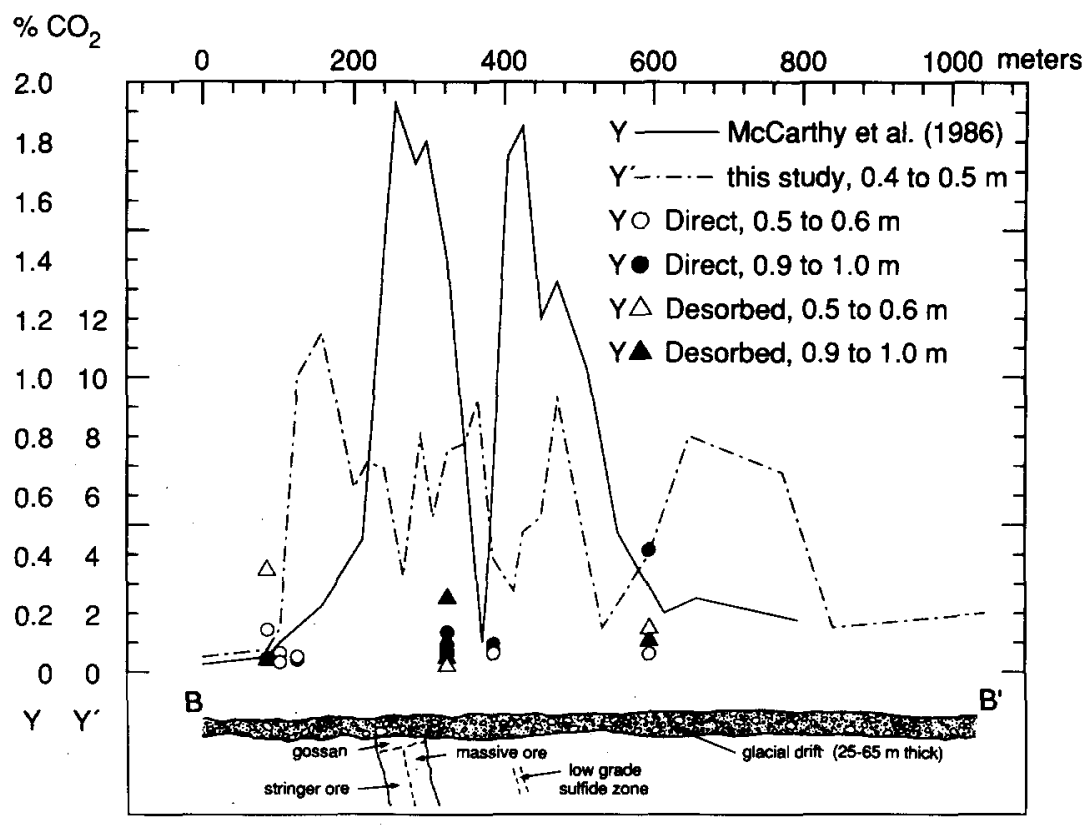

Fig. 2. $\mathrm{CO}_{2}$ concentrations in soil gas on traverse $B-B^{\prime}$ from this study compared with data of McCarthy et al. (1986). Solid line = McCarthy et al. (1986); dashed line = this study, 0.4- to $0.5-\mathrm{m}$ depth (note different scale, $Y^{\prime}$ ); open symbols = soil gas samples from $0.5-$ and $0.6-\mathrm{m}$ depth; solid symbols = samples from 0.9 - and 1.0-m depth; circles=direct gas samples; squares $=$ gases desorbed from soils at $170^{\circ} \mathrm{C}$.

ling, 1984). Increasing $\mathrm{CO}_{2}$ concentrations with depth were noted at three of the five sites sampled at multiple depths (sites $\mathrm{C} 12, \mathrm{C} 15$, and $\mathrm{C} 21$; Table 1 ). No clear pattern of $\mathrm{CO}_{2}$ concentration with depth is observed for the desorbed soil gases from these sites (Fig. 2; Table 2).

Stable isotope ratios for carbon and oxygen in soil-gas $\mathrm{CO}_{2}$ are shown on Table 1 and Figure 3. $\mathrm{CO}_{2}$ concentrations in background samples $\mathrm{C} 97, \mathrm{C} 98$ and $\mathrm{C} 99$ are lower than the samples taken closer to the sulfide deposit, however, the stable isotopes of $\mathrm{C}$ and $\mathrm{O}$ are indistinguishable. This suggests the possibility that similar mechanisms are responsible for $\mathrm{CO}_{2}$ generation in the two areas, although perhaps operating at a faster rate or over a greater surface area near to the sulfide zone.

The three pairs of samples taken without moving the probe at sites $\mathrm{C} 12$ and $\mathrm{C} 15$ showed no significant change in $\delta^{18} \mathrm{O}$ or $\delta^{13} \mathrm{C}$ of $\mathrm{CO}_{2}$ with time. This suggests that any atmospheric component of $\mathrm{CO}_{2}$ in the soil gas was introduced by natural diffusion and mixing within the soil rather than as an artifact of the sampling.

Major-element geochemistry and oxygen isotope ratios for two representa- 


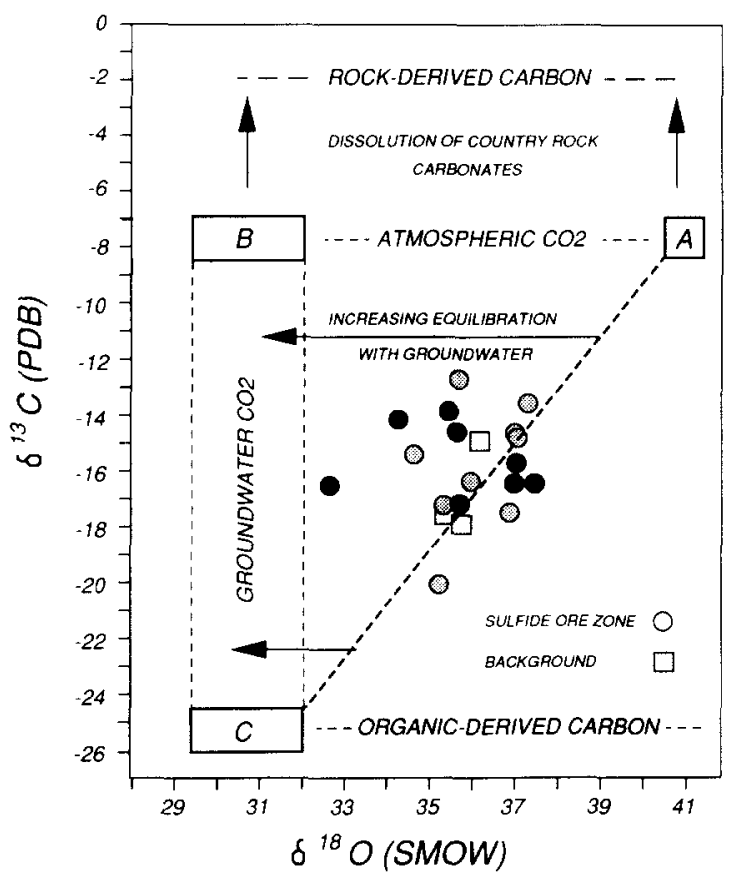

Fig. 3. $\delta^{13} \mathrm{C}$ vs. $\delta^{18} \mathrm{O}$ for soil-gas $\mathrm{CO}_{2}$. Solid circles=soil gas from 0.5 - and $0.6-\mathrm{m}$ depth; halftone circles = soil gas from 0.9 - and 1.0-m depth; squares = "background" samples, $1-2 \mathrm{~km}$ south of massive sulfide deposit (Fig. 1). Field $A=$ atmospheric $\mathrm{CO}_{2}$ (Keeling et al., 1979); Field $B=$ atmospheric $\mathrm{CO}_{2}$ in equilibrium with measured groundwater, calculated for a range of temperatures from $25^{\circ}$ to $15^{\circ} \mathrm{C}$ (Table 3 ); Field $C=$ organically derived carbon in equilibrium with groundwater.

tive groundwater samples are shown in Table 3. The $\delta^{18} \mathrm{O}$ values for the groundwaters are similar to present-day precipitation in northern Wisconsin (Yurtsever and Gat, 1981), so it is assumed that minimal evaporation and water-rock exchange have occurred. Also shown in Table 3 and on Figure 3 are the $\delta^{18} \mathrm{O}$ values for $\mathrm{CO}_{2}$ in equilibrium with the local groundwater, calculated at 15 and $25^{\circ} \mathrm{C}$ using a temperature-dependent fractionation factor (Friedman and O'Neil, 1977).

Sulfur dioxide $\left(\mathrm{SO}_{2}\right)$ was the only sulfur-bearing gas detected in the soilgas samples (Table 1). Based on experiments and field observations over oxidizing sulfide deposits, the gas species $\mathrm{COS}$ and $\mathrm{CS}_{2}$ are ordinarily more abundant than $\mathrm{SO}_{2}$ as the initial products of sulfide oxidation (Taylor et al., 1982; Oakes and Hale, 1987). It is possible that $\mathrm{COS}$ and $\mathrm{CS}_{2}$ were originally present, but oxidized to $\mathrm{CO}_{2}$ and $\mathrm{SO}_{2}$ between collection and analysis of our samples, a period of about three weeks. Traces of $\mathrm{H}_{2} \mathrm{~S}$ and $\mathrm{COS}$ were detected in gas desorbed from one of the nine soil samples analyzed in this manner (Table 2); $\mathrm{SO}_{2}$ was not detected in gas desorbed from any of the soil samples. 


\section{DISCUSSION}

\section{Carbon isotopes}

Stable isotopic data for soil-gas $\mathrm{CO}_{2}$ can potentially be used to identify the sources of both carbon and oxygen, and thereby shed light on the mechanism (s) of $\mathrm{CO}_{2}$ generation. Commonly observed ranges in $\delta^{13} \mathrm{C}$ for possible carbon sources are shown in Table 4. The most straightforward interpretation of the range in $\delta^{13} \mathrm{C}$ in soil-gas $\mathrm{CO}_{2}$ at Crandon is a mixture of two carbon sources: atmospheric $\mathrm{CO}_{2}$ and an organic-derived component.

Organic carbon in Crandon soils has a mean $\delta^{13} \mathrm{C}$ of $-25.1 \pm 0.4 \%$ (Table 2 ), yet the most negative $\delta^{13} \mathrm{C}$ observed in soil $\mathrm{CO}_{2}$ was $-20.0 \%$ (Table 1 ). The $\delta^{13} \mathrm{C}$ of possible carbon sources listed in Table 4 would suggest that the organic carbon in Crandon soils is derived primarily from $\mathrm{C}_{3}$ plants. No survey has been made of the actual grass species at Crandon. However, Crandon sits at a latitude $\left(45^{\circ} \mathrm{N}\right)$ that commonly hosts a mixed population of $\mathrm{C}_{3}$ and $\mathrm{C}_{4}$ plant species (Teeri and Stowe, 1976; Ode et al., 1980). Teeri and Stowe (1976) estimated that $34 \%$ of the grasses in the state of Wisconsin are of the $\mathrm{C}_{4}$ type, based on work by Fassett (1951). Vegetation types on the project site at Crandon have been described as $59 \%$ northern hardwood (sugar maple, basswood, yellow birch, eastern hemlock, aspen, paper birch ), 20\% swamp conifer (white cedar, balsam fir, black spruce, tamarack), and 3\% shrub swamp (speckled alder, sedges, blue-joint grass (Calamagrostis canadensis)) (Exxon, 1985). Because the peak photosynthetic activity of $\mathrm{C}_{3}$ and $\mathrm{C}_{4}$ plants tends to occur at different times of the year (Ode et al., 1980), one might expect considerable seasonal variation in the $\delta^{13} \mathrm{C}$ of soil-gas $\mathrm{CO}_{2}$ in areas with a mixed $\mathrm{C}_{3}-\mathrm{C}_{4}$ population. Such seasonal cycles in soil $\mathrm{CO}_{2}$ concentra-

\section{TABLE 4}

Possible carbon sources for soil-gas $\mathrm{CO}_{2}$

\begin{tabular}{lll}
\hline Carbon source & $\delta^{13} \mathrm{C}(\% \mathrm{PDB})$ & References \\
\hline Marine carbonate: Proterozoic & $0 \pm 2$ & Veizer and Hoefs (1976) \\
Marine carbonate: Paleozoic & -1 to 4 & Lohmann (1987) \\
Crandon soil carbonate & -1.8 & This study \\
Atmospheric $\mathrm{CO}_{2}$ & $-7 \pm 1$ & Keeling et al. (1979) \\
Fossil fuel $\mathrm{CO}_{2}$ atmosphere & -25.0 & Wallick (1976) \\
$\mathrm{C}_{4}$ plants & $-12.0 \pm 2$ & Salomons and Mook (1986) \\
$\mathrm{C}_{3}$ plants & $-27.0 \pm 2$ & Salomons and Mook (1986) \\
CAM plants & $-17.0 \pm 3(?)$ & Salomons and Mook (1986) \\
Crandon soil organic carbon & $-25.1 \pm 0.4$ & This study (Table 2) \\
\hline
\end{tabular}

${ }^{a}$ Carbonate isolated from soil sample $\mathrm{C}-12-1$ yielded $\delta^{13} \mathrm{C}=-1.8 \% 0(\mathrm{PDB})$ and $\delta^{18} \mathrm{O}=24.3 \%$ (SMOW). 
tion and $\delta^{13} \mathrm{C}$ have been noted elsewhere by Rightmire (1978) and by Fritz et al. (1978).

In addition to the carbon source, the $\delta^{13} \mathrm{C}$ of soil $\mathrm{CO}_{2}$ is influenced by several other processes, including the diffusion of $\mathrm{CO}_{2}$ to (and from) the atmosphere driven by concentration gradients and the rate of "soil respiration", defined by Cerling (1984) as the combined $\mathrm{CO}_{2}$ production from root respiration plus microbial oxidation of organic material in the soil. The $\delta^{13} \mathrm{C}$ of soil $\mathrm{CO}_{2}$ is, in general, less negative than overlying vegetation, showing an enrichment of 2.6 to $9.1 \%$ in central Florida (Rightmire and Hanshaw, 1973) and of 5 to $8 \%$ in northern Ontario (Fritz et al., 1978). The preferential uptake of ${ }^{12} \mathrm{C}$ by plants and the release of respired $\mathrm{CO}_{2}$ enriched in ${ }^{13} \mathrm{C}$ may provide a partial explanation of this phenomenon (Park and Epstein, 1960). Another possible explanation is that the different diffusion coefficients for ${ }^{13} \mathrm{C}$ and ${ }^{12} \mathrm{C}$ cause the net respired $\mathrm{CO}_{2}$ to be about $4 \%$ lighter in $\delta^{13} \mathrm{C}$ than the measured soil $\mathrm{CO}_{2}$ (Dörr and Münnich, 1980).

Field studies by Fritz et al. (1978) and theoretical modeling by Cerling (1984) have shown that the atmospheric component of soil-gas $\mathrm{CO}_{2}$ is important only when soil respiration rates are low. Our sampling at Crandon was done in late October, when one might expect the $\mathrm{C}_{3}$ plants to have dominated over $\mathrm{C}_{4}$ in terms of biomass and $\mathrm{CO}_{2}$ production (Ode et al., 1980). According to the model of Cerling (1984) (which assumed $\delta^{13} \mathrm{C}$ of $-6 \%$ for atmospheric $\mathrm{CO}_{2}$ and $-27 \%$ for $\mathrm{CO}_{2}$ respired from $\mathrm{C}_{3}$ vegetation ) one could expect $\delta^{13} \mathrm{C}$ values for soil $\mathrm{CO}_{2}$ ranging from -12 to $-20 \%$ at a depth of 0.5 $\mathrm{m}$, resulting from respiration rates of 0.1 to $1.3 \times 10^{-3}$ moles $\mathrm{m}^{-2} \mathrm{hr}^{-1}$. At a depth of $1.0 \mathrm{~m}$, soil respiration rates from about 0.05 to $1.05 \times 10^{-3}$ moles $\mathrm{m}^{-2} \mathrm{hr}^{-1}$ would be required for the same range in $\delta^{13} \mathrm{C}$ for soil $\mathrm{CO}_{2}$.

Two types of marine carbonate are potential sources of isotopically heavy carbon at Crandon: (1) Early Proterozoic carbonate associated with the bedrock and (2) Paleozoic carbonate transported to the area in the glacial till. No stable isotope measurements of Proterozoic carbonate were made for this study because carbonate minerals are rare in the ore zone and surrounding rocks (McCarthy et al., 1986); the $\delta^{13} \mathrm{C}$ of such material would probably be similar to other Proterozoic marine carbonates, $0 \pm 2 \%$ PDB (Veizer and Hoefs, 1976). Paleozoic marine carbonates, which occur elsewhere as clasts in glacial tills of Wisconsinan age (Burgis, 1977), typically have $\delta^{13} \mathrm{C}$ in a similar range, -2 to $+4 \%$ PDB (Lohmann, 1987).

The calcareous deposits that may develop in glacial till are in general made up primarily of carbonate derived from clasts in the till, plus a secondary component of pedogenic carbonate that may have formed during the glaciation. Unfortunately, we were unable to sample the till at Crandon to determine the $\delta^{13} \mathrm{C}$ of this calcareous material; we speculate that its $\delta^{13} \mathrm{C}$ would be dominated by the Paleozoic clasts in the till and therefore would be close to $0 \%$ (cf. Burgis, 1977). We were able to isolate a sufficient quantity of car- 
bonate from only one of the soil samples, which yielded a $\delta^{13} \mathrm{C}$ value of $-1.8 \%$ (Table 4). This analysis suggests a residual marine source as opposed to pedogenic carbonate formed in isotopic equilibrium with ambient soil $\mathrm{CO}_{2}$. Therefore, we assert that all carbonate minerals in the bedrock, till, and soil at Crandon may have $\delta^{13} \mathrm{C}$ near to $0 \%$, so that the absence of relatively heavy carbon in the soil gas $\mathrm{CO}_{2}$ would indicate relatively little contribution from carbonate dissolution.

A possible exception to this generalization would be if pedogenic carbonate which had formed at some time in the past were to have incorporated relatively light carbon. Quade et al. (1989) have shown that the $\delta^{13} \mathrm{C}$ (and $\delta^{18} \mathrm{O}$ ) of pedogenic carbonate varies systematically with climate and elevation. Perhaps during Pleistocene glacial periods, the climate at Crandon would have been conducive to production of pedogenic carbonate with light $\delta^{13} \mathrm{C}$; however, such material was not analyzed in this study.

\section{Oxygen isotopes}

The $\delta^{18} \mathrm{O}$ values in Crandon soil $\mathrm{CO}_{2}$ fall between the $\delta^{18} \mathrm{O}$ values for atmospheric $\mathrm{CO}_{2}$ and organic-derived $\mathrm{CO}_{2}$ in equilibrium with the Crandon groundwater (Table 3; Fig. 3). The data on Figure 3 are distributed near a mixing line between these two endmembers (points $A$ and $C$ ). Likely sources for $\delta^{18} \mathrm{O}$ in the soil $\mathrm{CO}_{2}$ include the $\mathrm{H}_{2} \mathrm{O}$ of the groundwater (pt. B) and recent precipitation, along with diffusive mixing of atmospheric $\mathrm{CO}_{2}$. Apparently, any $\mathrm{CO}_{2}$ generated by microbial oxidation of organic matter, where dissolved $\mathrm{O}_{2}$ acted as the oxidant, has apparently re-equilibrated its oxygen isotopes with the local groundwaters.

\section{Possible sources of $\mathrm{CO}_{2}$ anomaly}

We are left with three possible scenarios to explain our observations:

Scenario (1): The $\mathrm{CO}_{2}$ anomaly is caused by sulfide oxidation generating sulfuric acid which dissolves carbonates in the lower till (McCarthy et al., 1986). These carbonates have $\delta^{13} \mathrm{C}$ values near $0 \%$, largely inherited from Paleozoic limestone clasts. At the time of our sampling in late October, 1986, it had rained considerably in the previous 10-day period, causing saturated conditions in the upper part of the till that reduced the diffusion rate of $\mathrm{CO}_{2}$ to the surface (cf. McCarthy et al., 1986). Therefore, the $\mathrm{CO}_{2}$ anomaly was not particularly well developed, and no isotopic anomaly was detected. This scenario would predict significantly heavier $\delta^{13} \mathrm{C}$ in the soil-gas $\mathrm{CO}_{2}$ under drier conditions.

Scenario (2): The $\mathrm{CO}_{2}$ anomaly is caused by sulfide oxidation generating acid which dissolves carbonates in the lower till. These carbonates could have relatively light $\delta^{13} \mathrm{C}$ values, perhaps -10 to $-15 \%$, if formed during a glacial 
episode. This scenario would predict no isotopic anomaly in the soil-gas $\mathrm{CO}_{2}$, even under drier conditions when the $\mathrm{CO}_{2}$ anomaly would be better developed, because the additional $\mathrm{CO}_{2}$ would have a very similar $\delta^{13} \mathrm{C}$ signature to the soil gas formed by "background" processes not affected by sulfide oxidation.

Scenario (3): The $\mathrm{CO}_{2}$ anomaly is only indirectly related to the sulfide mineralization. One possibility is that sulfide oxidation at depth raises the ambient temperature slightly in this zone, which causes increased rates of biological activity and more $\mathrm{CO}_{2}$ production. Another possibility is that physical properties of the sulfide zone and overlying till have led to more humid conditions above the sulfide zone. Detailed surveys of temperature and soil moisture content could rather easily test these ideas. Neither of these somewhat remote possibilities would lead to a significant stable isotopic anomaly, except in the unlikely event that the temperature effect was found to be several degrees centigrade.

\section{CONCLUDING REMARKS}

The source of anomalous $\mathrm{CO}_{2}$ concentrations in soil gas over sulfide mineralization at Crandon, Wisconsin cannot be determined unequivocally by the presently available stable isotopic data, however, certain limits can be placed on some of the possibilities. The simplest explanation of the carbon isotope data is mixing from two sources: atmospheric $\mathrm{CO}_{2}$ and the root respiration and/or microbial breakdown of $\mathrm{C}_{3}$ plant material. The results of Cerling's (1984) model for $\mathrm{CO}_{2}$ diffusion in soils indicates that soil respiration rates must be low for the atmospheric component to dominate, which is what one would expect for the season in which the samples were collected for this preliminary study. No evidence was found for a marine carbonate component to the $\delta^{13} \mathrm{C}$ in the soil-gas $\mathrm{CO}_{2}$, however the sampling was done at a time when the $\mathrm{CO}_{2}$ anomaly was not particularly well developed because of recent precipitation.

The data for $\delta^{18} \mathrm{O}$ in soil-gas $\mathrm{CO}_{2}$ indicate that the oxygen appears to be in approximate equilibrium with ambient groundwater, with some intermixture of atmospheric $\mathrm{CO}_{2}$. Any $\mathrm{CO}_{2}$ generated by microbial oxidation of organic matter by dissolved $\mathrm{O}_{2}$ has equilibrated its oxygen isotopes with the ambient groundwater.

At the time of our soil-gas survey, there was nothing unusual about the stable isotopes of soil-gas $\mathrm{CO}_{2}$ at Crandon compared with other settings not located above massive sulfide deposits. However, because the sampling was unfortunately carried out at a time when the $\mathrm{CO}_{2}$ anomaly was not particularly well developed, the cause of the anomalous $\mathrm{CO}_{2}$ concentrations observed above the sulfide deposit on several other occasions remains open to interpretation. Dissolution of Proterozoic carbonates in bedrock below the water ta- 
ble in response to sulfide oxidation can probably be ruled out based on the relatively light carbon in the soil $\mathrm{CO}_{2}$ and the scarcity of such material in the underlying bedrock. A more likely scenario is dissolution of carbonates in the lower till above the sulfide ore, near the present water table. Because the $\delta^{13} \mathrm{C}$ of the till carbonates have not been determined, it remains an open question whether or not one should expect an isotopic anomaly along with the positive $\mathrm{CO}_{2}$ and negative $\mathrm{O}_{2}$ anomalies, which are better developed under drier conditions (McCarthy et al., 1986).

Clearly, more work is needed to document the temporal variations of $\mathrm{CO}_{2}$ anomalies over sulfide deposits and to relate these anomalies to biogeochemical mechanisms and inorganic reactions operative in soils and underlying deposits. Given the complexity of carbon isotope systematics in soil systems, especially in areas of mixed $\mathrm{C}_{3}-\mathrm{C}_{4}$ or CAM vegetation (Ode et al., 1980; Deines, 1980; Salomons and Mook, 1986), we recommend that baseline studies of the vegetation types in a given area be carried out before attempting to use $\delta^{13} \mathrm{C}$ in soil gas $\mathrm{CO}_{2}$ for exploration purposes. In an advantageous setting, such as one with isotopically homogeneous vegetation, there is considerable potential to sort out the mechanisms of soil-gas $\mathrm{CO}_{2}$ generation using stable isotopes.

Sulfur-bearing soil gases are a more direct and apparently more reliable indicator of buried sulfide mineralization than $\mathrm{CO}_{2}$. Nevertheless, for studies of soil-gas genesis, $\mathrm{CO}_{2}$ has the advantages of greater abundance and relative ease of separation, allowing the study of stable isotopes. More comprehensive studies of seasonal and diurnal variations of $\mathrm{CO}_{2}$ concentrations and stable isotope compositions may ultimately resolve the source of anomalous $\mathrm{CO}_{2}$ over oxidizing sulfide deposits. However, the results from this preliminary study indicate that one should not attempt to use stable isotope data as a means to discriminate between $\mathrm{CO}_{2}$ anomalies in the absence of other data.

\section{ACKNOWLEDGEMENTS}

The authors are very grateful to $O$. Warin at Utah International, Inc. for financial support and to R. Rowe, F. Sonderman, and T. Tresell at Exxon Coal and Minerals for permission to visit Crandon and to publish these results. Thanks are due to S.E. Kesler for advice on sampling techniques and for allowing the use of his gas sampling equipment. Luis Gonzales assisted with sample preparation and stable isotope analysis. Organic carbon and nitrogen analysis by Phil Meyers' group is also much appreciated. Field assistance by D. Kinkaid was essential. Jeanne Dileo-Stevens assisted with preparation of the figures. This report was prepared while the senior author was a post-doctoral resident research associate, sponsored by the National Research Council and the Water Resources Division of the U.S. Geological Survey. 


\section{REFERENCES}

Amundson, R.G., Chadwick, O.A., Sowers, J.M. and Doner, H.E., 1988. Relationship between climate and vegetation and the stable carbon isotope chemistry of soils in the Eastern Mojave Desert, Nevada. Quat. Res., 29: 245-254.

Ball, T.K., Hextall, J.P., Nicholson, R.A. and Preachey, D., 1983. Application of Orsat stackgas analyser to geochemical exploration research. Trans. Inst. Min. Metall. (Sect. B., Appl. Earth Sci. ), 92B: 49-51.

Bender, M.M., 1968. Mass spectrometric studies of carbon-13 variations in corn and other grasses. Radiocarbon, 10: 468-472.

Bender, M.M., 1971. Variations in the ${ }^{13} \mathrm{C} /{ }^{12} \mathrm{C}$ ratios of plants in relation to the pathway of photosynthetic carbon dioxide fixation. Phytochemistry, 10: 1239-1244.

Burgis, W.A., 1977. Late Wiconsinan history of northeastern lower Michigan. Ph.D. thesis, Univ. of Michigan, Ann Arbor, MI, 396 pp. (unpubl.)

Buyanovsky, G.A. and Wagner, G.H., 1983. Annual cycles of carbon dioxide level in soil air. Soil Sci. Soc. Am. Proc., 47: 1139-1145.

Calvin, M. and Bassham, J.A., 1962. The Photosynthesis of Carbon Compounds. Benjamin, New York, NY.

Cerling, T.E., 1984. The stable isotopic composition of modern soil carbonate and its relationship to climate. Earth Planet Sci. Lett., 71: 229-240.

Cerling, T.E. and Hay, R.L., 1986. An isotopic study of paleosol carbonates from Olduvai Gorge. Quat. Res., 25: 63-78.

Cerling, T.E., Hay, R.L. and O'Neil, J.R., 1977. Isotopic evidence for dramatic climatic changes in East Africa during the Pleistocene. Nature (London), 267: 137-138.

Clifton, C.G., 1984a. Examples of primary gas dispersion in several disseminated gold deposits in Nevada and California. Preliminary Report I, Exploration Research Laboratories, Corvallis, OR, 33 pp. (unpubl.)

Clifton, C.G., 1984b. Interpretation of soil gas data $\left(\mathrm{CO}_{2}, \mathrm{CS}_{2}, \mathrm{COS}, \mathrm{SO}_{2}, \mathrm{H}_{2} \mathrm{~S}\right)$. Preliminary Report II, Exploration Research Laboratories, Corvallis, OR, 22 pp. (unpubl.)

Deines, P., 1980. The isotopic composition of reduced organic carbon. In: P. Fritz and J.Ch. Fontes (Editors), Handbook of Environmental Isotope Geochemistry, V. 1, The Terrestiral Environment, A. Elsevier, Amsterdam, pp. 329-406.

Dörr, H. and Münnich, K.O., 1980. Carbon-14 and carbon-13 in soil $\mathrm{CO}_{2}$. Radiocarbon, 22: 909-918.

Exxon, 1986. Final Environmental Impact Statement, Exxon Coal and Minerals Company, ZincCopper Mine, Crandon, Wisconsin. Wisconsin Dep. Natural Resources, 446 pp. (unpubl.).

Fassett, N.C., 1951. Grasses of Wisconsin. Univ. of Wisconsin Press, Madison, WI, pp. 1-173.

Friedman, I. and O'Neil, J.R., 1977. Compilation of stable isotope fractionation factors of geochemical interest. In: M. Fleisher (Editor), Data of Geochemistry, Sixth Edition. U.S. Geol. Surv., Prof. Pap. 440-KK, 12 pp.

Fritz, P., Reardon, E.J., Barker, J., Brown, R.M., Cherry, J.A., Killey, R.W.D. and MacNaughton, D., 1978. The carbon isotope geochemistry of a small groundwater system in Northeastern Ontario. Water Resour. Res., 14: 1059-1067.

Hale, M. and Moon, C.J., 1982. Geochemical expressions at surface of mineralization concealed beneath glacial till at Keel, Eire. In: P.H. Davenport (Editor), Prospecting in Areas of Glaciated Terrain-1982. Can. Inst. Min. Metall., 5th Symp., St. John's. Nfld, pp. 228239.

Hatch, M.D., Slack, R.C. and Johnson, H.S., 1967. Further studies on a new pathway of photosynthetic carbon dioxide fixation in sugarcane and its occurrence in other plant species. Biochem. J., 10: 417-422.

Hillaire-Marcel, G., 1986. Isotopes and food. In: P. Fritz and J.Ch. Fontes (Editors), Hand- 
book of Environmental Isotope Geochemistry, V. 2, The Terrestrial Environment, B. Elsevier, Amsterdam, pp. 507-548.

Keeling, C.D., Mook, W.G. and Tans, P.P., 1979. Recent trend in the ${ }^{13} \mathrm{C} /{ }^{12} \mathrm{C}$ ratio of atmospheric carbon dioxide. Nature, 277: 121-123.

Kluge, M. and Ting, I.P., 1978. Crassulacean acid metabolism: analysis of an ecological adaptation. In: W.D. Billings, F. Golley, O.L. Lange and J.S. Olson (Editors), Ecological Studies: Analysis and Synthesis, 30. Springer, Berlin, 209 pp.

Lerman, J.C., 1972. Soil- $\mathrm{CO}_{2}$ and groundwater: carbon isotope compositions. In: T.A. Rafter and T. Grant-Taylor (Editors), Proc. Eighth Intl. Radiocarbon Dating Conf., Lower Hutt, New Zeal., Royal Soc. New Zeal., pp. D93-D105.

Lohmann, K.C., 1987. Geochemical patterns of meteoric diagenetic systems and their application to studies of paleokarst. In: N.P. James and P.W. Choquette (Editors), Studies in Paleokarst. Soc. Econ. Paleontol. Mineral., Spec. Publ. Tulsa, Oklahoma, pp. 58-80.

Lovell, J.S., Hale, M. and Webb, J.S., 1983. Soil air carbon dioxide and oxygen measurements as a guide to concealed mineralization in semi-arid and arid regions. In: G.R. Parslow (Editor), Geochemical Exploration 1982. J. Geochem. Explor., 19: 305-317.

Lundegardh, H., 1927. Carbon dioxide evolution of soil and crop growth. Soil Sci., 23: 417453.

Margaritz, M., Kaufman, A. and Yaalon, D., 1981. Calcium carbonate nodules in soils: ${ }^{18} \mathrm{O} /$ ${ }^{16} \mathrm{O}$ and ${ }^{13} \mathrm{C} /{ }^{12} \mathrm{C}$ ratios and ${ }^{14} \mathrm{C}$ contents. Geoderma, 25: 157-172.

May, E.R. and Schmidt, P.G., 1982. The discovery, geology, and mineralogy of the Crandon Precambrian massive sulphide deposit, Wisconsin. In: R.W. Hutchinson et al. (Editors), Precambrian Sulphide Deposits, Geol. Assoc. Can., Spec. Pap., 25: 447-480.

McCarthy, Jr., J.H., Lambe, R.N. and Dietrich, J.A., 1986. A case study of soil gases as an exploration guide in glaciated terrain - Crandon massive sulfide deposit, Wisconsin. Econ. Geol., 81: 408-420.

Oakes, B.W. and Hale, M., 1987. Dispersion patterns of carbonyl sulphide above mineral deposits. J. Geochem. Explor., 28: 235-249.

Ode, D.J., Tieszen, L.L. and Lerman, J.C., 1980. The seasonal contribution of $\mathrm{C}_{3}$ and $\mathrm{C}_{4}$ plant species to a primary production in a mixed prairie. Ecology, 61: 1304-1311.

Parada, C.B., Long, A. and Davis, S.N., 1983. Stable-isotopic composition of soil carbon dioxide in the Tucson Basin, Arizona, U.S.A. Isot. Geosci. (Chem. Geol.), 1: 219-236.

Park, R. and Epstein, S., 1960. Carbon isotope fractionation during photosynthesis. Geochim. Cosmochim. Acta, 21: 110-126.

Quade, J., Cerling, T.E. and Bowman, J.R., 1989. Systematic variations in the carbon and oxygen isotopic composition of pedogenic carbonate along elevation transects in the southern Great Basin, United States. Geol. Soc. Am. Bull., 101: 464-475.

Reardon, E.J., Allison, G.B. and Fritz, P., 1979. Seasonal chemical and isotopic variations of soil $\mathrm{CO}_{2}$ at Trout Creek, Ontario. J. Hydrol., 43: 355-371.

Rightmire, C.T., 1978. Seasonal variations in $\mathrm{P}_{\mathrm{CO}_{2}}$ and ${ }^{13} \mathrm{C}$ content of soil atmosphere. Water Resour. Res., 14: 691-692.

Rightmire, C.T. and Hanshaw, B.B., 1973. Relationship between the carbon isotope composition of soil $\mathrm{CO}_{2}$ and dissolved carbonate species in groundwater. Water Resour. Res., 9: 958967.

Salomons, W. and Mook, W.G., 1986. Isotope geochemistry of carbonates in the weathering zone. In: P. Fritz and J.Ch. Fontes (Editors), Handbook of Environment Isotope Geochemistry, V. 2, The Terrestrial Environment, B. Elsevier, Amsterdam, pp. 239-269.

Schmidt, P.G., Dolence, J.D., Lluria, M.R. and Parsons III., G., 1978. Geology of the Crandon massive sulfide deposit, Forest County, Wisconsin. Eng. Min. J., 179(7): 61-66.

Smith, B.N. and Epstein, S., 1971. Two categories of ${ }^{13} \mathrm{C} /{ }^{12} \mathrm{C}$ ratios for higher plants. Plant Physiol., 47: 380-384. 
Talma, A.S. and Netterberg, F., 1983. Stable isotope abundances in calcretes. In: R.C.L. Wilson (Editor), Residual deposits: Surface Related Weathering Processes and Materials. Geol. Soc. (London) Spec. Publ., 11: 221-233.

Taylor, C.H., Kesler, S.E. and Cloke, P.L., 1982. Sulphur gases produced by the decomposition of sulphide minerals: application to geochemical exploration. J. Geochem. Explor., 17: 165185.

Teeri, J.A. and Stowe, L.G., 1976. Climatic patterns and the distribution of $\mathrm{C}_{4}$ grasses in North America. Oecologia, 23: 1-12.

Von Bavel, C.H.M., 1951. A soil aeration theory based on diffusion. Soil Sci., 72: 33-46.

Veizer, J. and Hoefs, J., 1976. The nature of ${ }^{18} \mathrm{O} /{ }^{16} \mathrm{O}$ and ${ }^{13} \mathrm{C} /{ }^{12} \mathrm{C}$ secular trends in sedimentary carbonate rocks. Geochim. Cosmochim. Acta, 40: 1387-1395.

Wallick, E.I., 1976. Isotopic and chemical considerations in radiocarbon dating of groundwater within the semi-arid Tucson Basin, Arizona. In: Interpretation of environmental isotope and hydrochemical data in groundwater hydrology. Int. Atomic Energy Agency, Vienna, Panel Proc. Ser., pp. 195-212.

Wallick, E.I., Trudell, M., Moran, S.R., Shakur, A. and Krouse, H.R., 1984. Carbon dioxide content and isotopic composition of gas in the unsaturated zone as an index of geochemical activity in reclaimed mineral lands, Alberta, Canada [abstr.]. In: Isotope Hydrology 1983. Int. Atomic Energy Agency, Vienna, SM-270, p. 823.

White, A.F. and Chuma, N.J., 1987. Carbon and isotopic mass balance models of Oasis ValleyFortymile Canyon Groundwater Basin, southern Nevada. Water Resour. Res., 23: 571-582.

Wigley, T.M.L., 1975. Carbon-14 dating of groundwater from closed and open systems. Water Resour. Res., 11: 324-328.

Yurtsever, Y. and Gat, J.R., 1981. Atmospheric waters. In: J.R. Gat and R. Gonfiantini (Editors ), Stable Isotope Hydrology: Deuterium and Oxygen-1 8 in the Water Cycle., Int. Atomic Energy Agency, Vienna, Tech. Rep., 210: 103-142. 